\title{
Subregional Governance of Bus Services: An Integrated Study
}

\author{
Xueming Chen, California State University, Northridge
}

\begin{abstract}
As one type of transportation governance model, subregional governance of bus services intends to improve customer responsiveness and cost effectiveness of bus service provision, with economic, political, and operational impacts.

This article compares merits and demerits of three alternatives of subregional governance: transferring bus services to local municipal operators, transferring bus services to local transportation zones, and reorganizing transit operations into bus service sectors. Los Angeles County's Foothill Transit, is an example of a successful local transportation zone. Authorities are now in the process of creating bus service sectors. While a promising venture, the system is still in its infancy and lacks actual performance data.

Though an optimal subregional governance model fitting every circumstance does not exist, a mixed alternative balancing regional interests and local interests, and reconciling the conflicts among different governance models seems feasible.

\section{Introduction}

As an integral component of transportation governing strategies, subregional governance of bus services has become a popular planning strategy in the U.S. transit industry. For example, large and politically complicated metropolitan areas, such as New York, Los Angeles, Chicago, and San Diego, have embarked on subregionally
\end{abstract}


governing their bus services. This is not coincidental. Governance sustainability has been regarded as one of the prerequisites for achieving transportation sustainability (Schipper 2002). Yet, how to govern a particular transportation system to ensure its customer responsiveness and cost effectiveness is still debatable.

In its very essence, subregional governance represents one type of decentralized governance model, aiming at remedying flaws existing in the centralized governance model. The extent to which a decentralized or a centralized governance model is ultimately successful or not depends on many factors, including area geographic size, local political complexity, demographic characteristics of transit riders, operating characteristics of transit operators, economies of scale, and others. There is no universally applicable governance model fitting each particular circumstance.

This article describes an integrated study of subregional governance of bus services by using the Los Angeles County bus system as an empirical example. Research results reveal the existence of different trade-off options in undertaking subregional governance of bus services, and the preference of establishing a mixed alternative balancing regional interests and local interests, and reconciling conflicts among different governance models.

\section{Research Methodology}

A case study of subregional governance of bus services in Los Angeles County was conducted, through which economic, political, and operational impacts of this planning strategy can be assessed, and different subregional governance alternatives can be compared. The Los Angeles County case study may shed light on some of the issues associated with this planning strategy.

This article begins with a discussion of the literature review conducted to define the concept of governance, and summarize previous research findings. It then elucidates the rationale of subregional governance of bus services supported by the U.S. public transit data. Next, different alternatives and options of subregional governance of bus services as experimented in the United States are described and compared. This is followed by the case study of subregional governance of bus services in Los Angeles County, and an analysis of its key issues. The article concludes with a summary of research findings and suggested guidelines for further policy analysis related to transit service delivery systems. 


\section{Literature Review}

\section{Conceptual Definition of Governance}

There is no universally agreed on definition of the concept of "governance." Lowery (2002) shrugs off the concept of "governance" to be "one of those concepts like development or democratization that is so broad as to defy easy capture." Nevertheless, it is still necessary to go over several key definitions to guide this study.

According to Lynn, Heinrich, and Hill (2000), "governance generally refers to the means for achieving direction, control, and coordination of wholly or partially autonomous individuals or organizations on behalf of interests to which they jointly contribute."

Keohane and Nye (2000) define "governance" to be "the process and institutions, both formal and informal, that guide and restrain the collective activities of a group." The nation-state is the primary instrument of domestic and global governance.

Williamson (1999) defines the concept of "governance" as "the means by which order is accomplished in a relation in which potential conflict threatens to undo or upset opportunities to realize mutual gains."

Peters and Savoie (1995) note that "the root word for governance, and also for government, refers to steering.....ability of human institutions to control their societies and their economies." Governance has something to do with the political system, or the "State," which is the mechanism selected to provide collective direction to society. By employing its right to issue laws, its capacity to tax and spend, and its power to use coercion legitimately, the political system can attempt to shape the society in the ways desired.

Therefore, the concept of "governance" is closely related to management, coordination, public administration, and others. The narrowly defined concept of "governance" is connotative of the "state" functions of government agencies. But, the broadly defined concept of "governance" refers to both public and private guidance and coordination.

Governance can either be centralized or decentralized in terms of its actual operating mode. Subregional governance of bus services referred to in this article represents one type of decentralized governance model, which intends to provide an alternative to the centralized governance model by rendering more responsive customer services with more local controls. 


\section{Research Findings on Subregional Governance}

Lynn, Heinrich, and Hill (2000) argue that "if policy makers and public managers are to decentralize program operations and bring services closer to the people who are served, they must know how to ensure accountability and good practices cross diverse service units in dispersed locations." More specifically, how much formal control should be retained by authoritative decision-makers and how much should be delegated to subordinates and officers? How do the answers to this question vary across political and professional contexts? How can dispersed governance regimes be induced to converge on the achievement of particular policy objectives? These issues are directly relevant to the subregional governance of bus services examined in this article.

From the perspective of Deb, there are two main global trends in the restructuring of public transport. The first is to unbundle the monolithic and integrated services into more manageable and compact constituent units. The second trend is to segregate policy and planning from operational functions (Deb 2002). These two trends exactly reflect the purposes of subregional governance of bus services, under which headquarter agency will be responsible for setting policies and undertaking planning activities, whereas subordinate units will assume operational responsibilities.

Two consultant studies are directly related to this research topic: "Subregional Governance of MTA Services" prepared by Booz-Allen \& Hamilton, Inc. and others in June 1998; and "Subregional Government Alternatives Study" prepared by Weslin Consulting Services in November 2000. The Booz-Allen \& Hamilton report analyzes bus service divestiture priorities, stakeholder interests in divestiture, potential community impacts, cost and revenue implications, legal implications, and service delivery issues of different subregional governance alternatives. As a new task of the Southeast Bus Restructuring Study conducted for the Los Angeles County Metropolitan Transportation Authority (MTA), the Weslin Consulting report identifies six alternatives with a comparison of their advantages and disadvantages: (1) status quo; (2) MTA partnership; (3) partnership with included municipal operators; (4) joint powers agreement; (5) Southeast Community Development Corporation serves as lead agency; and (6) create a transportation zone. However, the report did not give any recommendations. 
Based on the above literature review, this study unfolds a comprehensive research probing the major issues and alternatives associated with the subregional governance of bus services, using the Los Angeles County bus system as an empirical case.

\section{Rationale of Subregional Governance of Bus Services}

For bus services in a large and politically complicated geographic area, a subregional governance planning strategy will generate significant impacts as discussed below.

\section{Economic Impact: Improve Economies of Scale}

The 2000 National Transit Database (NTD) maintained by the Fede ral Transit Administration (FTA) includes audited cost and operational data on more than 341 North American transit service providers, which is indicative of trends and patterns of the U.S. transit industry.

As indicated in Table 1, across the 341 bus transit operators reporting on the 2000 NTD, cost per hour of service increases, on average, with the size of the peak bus fleet. This reveals the existence of diseconomies of scale in transit service provision. Cost per bus hour of service consists of such components as operations labor and services, materials and fuel, overhead, finance, security, customer relations, and others.

\section{Table1. Municipal Bus Transit Operating Cost per Hour by} Peak Bus Fleet Size

Source: Federal Transit Administration. 2000. The National Transit Database. Washington, DC: U.S. Department of Transportation.

\begin{tabular}{|c|c|}
\hline Peak Bus Fleet Size & Transir Operating Cost Per Hour \\
\hline $0-50$ & $\$ 52.86$ \\
\hline $51-250$ & $\$ 57.52$ \\
\hline $251-500$ & $\$ 83.48$ \\
\hline $501-1200$ & $\$ 69.40$ \\
\hline$>1200$ & $\$ 97.81$ \\
\hline
\end{tabular}


Compared to a large transit operator, a small transit operator typically has a relatively weak union representing its contracted workers. Consequently, a small transit operator tends to have a lower bus driver wage rate. Bus driver wage rate is also affected by other factors, including the local cost of living and historical salary levels. For example, in 1997, the Los Angeles County MTA, with a bus fleet of 2,350, had a top bus driver wage rate of $\$ 19.61$ per hour. In the same year, Foothill Transit in Los Angeles County, with a bus fleet of 287, had a top bus driver wage rate of as low as $\$ 12.21$ per hour. Evidence suggests that a large transit operator tends to be more bureaucratic with a less efficient and a less flexible transit service delivery system, which results in a higher total operating cost. In 1997, MTA had a top systemwide cost per bus service hour of $\$ 98$ per hour; Foothill Transit had a much lower top systemwide cost per bus service hour of $\$ 58$ per hour (Booz-Allen \& Hamilton Inc. et al. 1998).

Subregional divestiture or governance of bus services would presumably reduce bus fleet size for each new operating unit, which would improve the overall economies of scale and reduce the total systemwide bus operating cost.

Additionally, other impacts are central to this process, including the following political and operational impacts.

\section{Political Impact: Strengthen Local Control}

Subregional governance may increase the degree of local control over transit policy, planning, and service delivery, thus harmonizing the relationship between a regional transit operator and its local jurisdictions.

A regional transit operator would gain more political support from local jurisdictions by implementing subregional governance strategies. Local support and participation is vital to adopting regional transportation plans, implementing transportation projects, and achieving transportation sustainability.

\section{Operational Impact: Improve Transit Operation}

Subregional governance of bus services may better meet bus rider needs and expectations for safe, quality bus transit services at a reasonable fare.

Since the primary purpose of subregional governance is to improve local bus operations and customer satisfaction, it may have the potential risk of disrupting regional bus operations and causing inconsistent bus operating schedules, transfer connectivity, and fare media acceptance among different subregional transit operators. Therefore, regional interests and local interests should properly be bal- 
anced. Only through a concerted and coordinated action among regional transit operators and subregional transit operators will the subregional governance of bus services maintain and improve the level of transit service integration, and accommodate seamless travel between and among alternative transit service providers. As a result, the overall cost of providing bus transit services would be lower, and the effectiveness of scarce resources would be enhanced.

\section{Alternatives of Subregional Governance of Bus Services}

There are many alternatives to subregional governance of bus services. Each alternative has advantages and disadvantages. This section introduces and evaluates three broad types of subregional governance strategies with different options, as shown in Figure 1.

\section{Figure 1. Subregional Governance of Bus Services Evaluation Flow Chart}

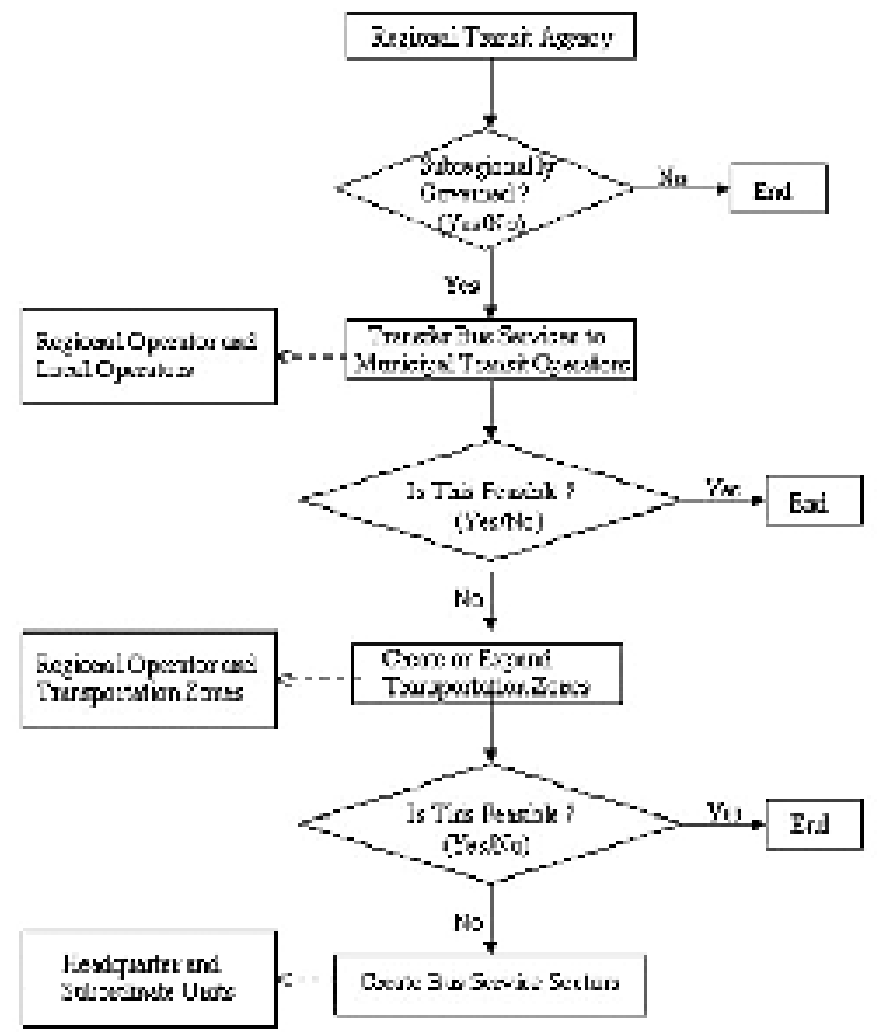




\section{Transfer Certain Bus Services to Existing Municipal Transit Operators}

This alternative would transfer certain bus services from a regional transit operator to several smaller municipal transit operators, as shown in Figure 2.

\section{Figure 2. Transfer Bus Routes from Regional Transit Operator to Municipal Transit Operators}

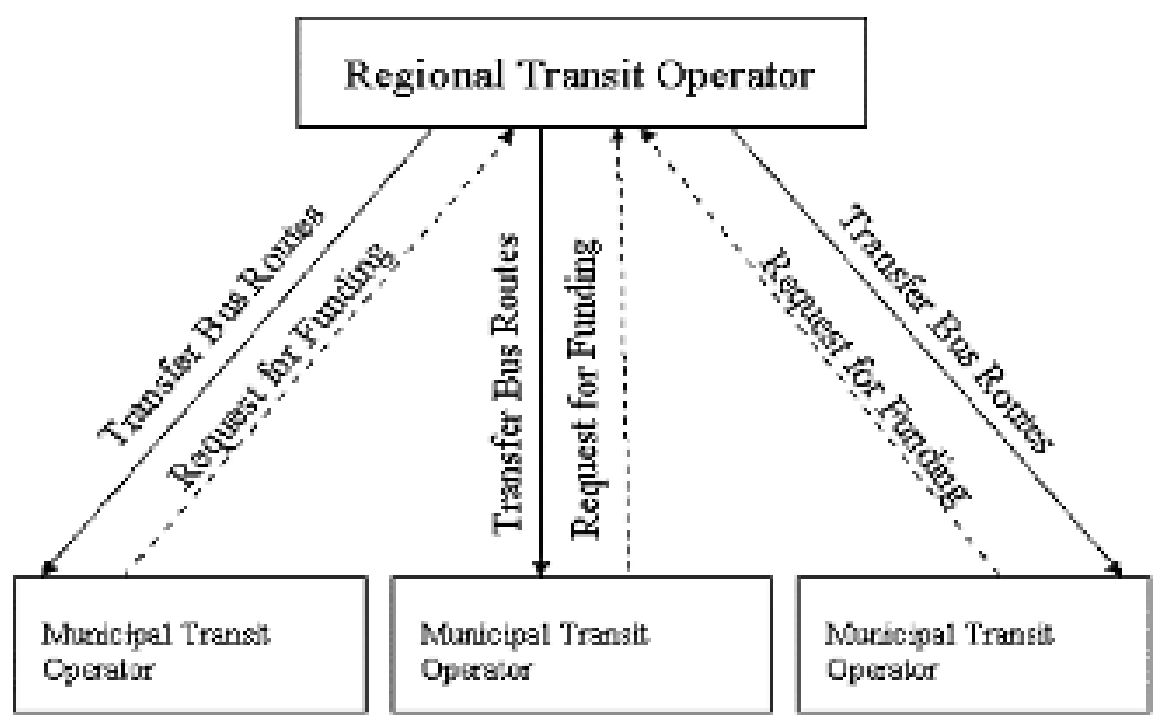

A couple of options may exist:

- Option 1: The regional transit operator only transfers local community and connector services to municipal transit operators, while retaining core regional services for itself, provided there exist three tiers of transit services: Tier 1-Regional service; Tier 2-Community service; and Tier 3-Connector service.

- Option 2: Municipal transit operators can freely choose bus routes of any tiers to be transferred, and the existing regional transit operator only fills in "white spaces" (i.e., operate whatever bus routes are left).

- Option 3: The regional transit operator transfers high-cost, low-use bus routes to municipal transit operators to improve the overall bus system efficiency and effectiveness. Some poor-performing bus routes could become good routes to be transferred. 
For each option, municipal transit operators would impose certa in conditions, especially funding conditions, before accepting divested bus routes from the regional transit operator. Table 2 shows the merits and demerits of each option. Option 1 is superior to both Options 2 and Option 3. In actuality, the mixed option may be chosen, under which the regional transit operator would retain core bus services while transferring some inefficient local bus routes to municipal transit operators.

\section{Table 2. Merits and Demerits of Transferring Bus Services to Municipal Transit Operators}

\begin{tabular}{|c|c|c|}
\hline Options & Merits & Demerits \\
\hline Option 1 & $\begin{array}{l}\text { Represencs a delicare balance } \\
\text { betwest maintaining } \\
\text { reponal transir service } \\
\text { continuty and improving } \\
\text { lacal transic service efficiency. }\end{array}$ & $\begin{array}{l}\text { The houndary berween } \\
\text { regional service and local } \\
\text { service is snmetimes fuzzy. }\end{array}$ \\
\hline Optien 2 & $\begin{array}{l}\text { Municipal transit operators } \\
\text { can fresly cheose bus routes } \\
\text { that most benefic local } \\
\text { communities and elirninate } \\
\text { duplications with ensting } \\
\text { laca bus rautes run by the } \\
\text { repional transir operaror. }\end{array}$ & 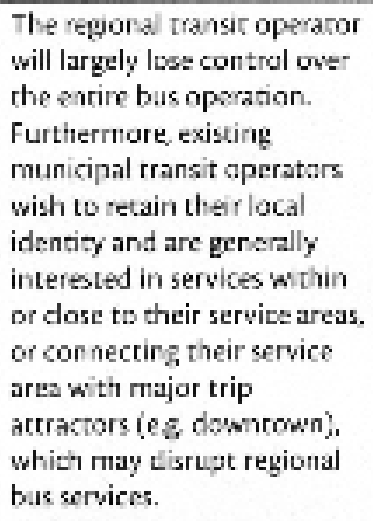 \\
\hline Optien 3 & $\begin{array}{l}\text { Oramaticaly reduce bus } \\
\text { openating pasts and improwe } \\
\text { bus operang efficiency. }\end{array}$ & $\begin{array}{l}\text { Existing municipal transit } \\
\text { vperaturs cannot afford to } \\
\text { run those mosr costly bus } \\
\text { routes witheut immediate } \\
\text { funding providad by the } \\
\text { regional large transic } \\
\text { operater. Sn, there is likely a } \\
\text { limir to the anount of bus } \\
\text { service which can be } \\
\text { resanably divested under } \\
\text { rhis oprion. }\end{array}$ \\
\hline
\end{tabular}




\section{Transfer Certain Bus Services to Existing or New Transportation Zones}

The Los Angeles County MTA stipulated the following four guiding principles for creation of a transportation zone (Los Angeles County MTA 1999):

- Improve the cost effectiveness of providing transportation services in Los Angeles County

- Increase local control of transportation services

- Increase the amount of transportation services in Los Angeles County

- Preserve other transit services in the County

As shown in Figure 3, this transportation zone alternative has two options.

- Option 1: Expand the existing transportation zone boundary and transfer some bus routes from the regional transit operator to the existing transportation zone.

- Option 2: Establish new zone(s) in the appropriate area to receive new bus routes to be transferred from the regional transit operator.

The merits and demerits of these two options are summarized in Table 3.

\section{Figure 3. Transfer Bus Routes from Regional Transit Operator to Local Transportation Zones}

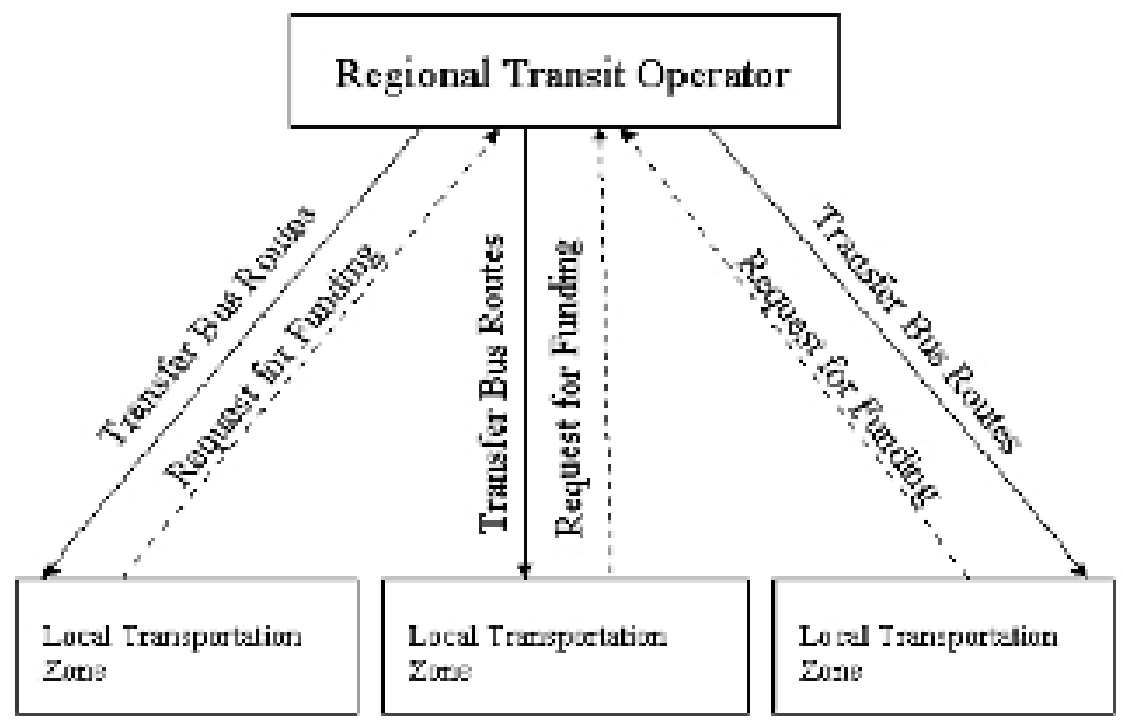




\section{Table 3. Merits and Demerits of Expanding or Establishing Transportation Zones}

\begin{tabular}{|c|c|c|}
\hline Options & Merits & Demerits \\
\hline coprion 1 & 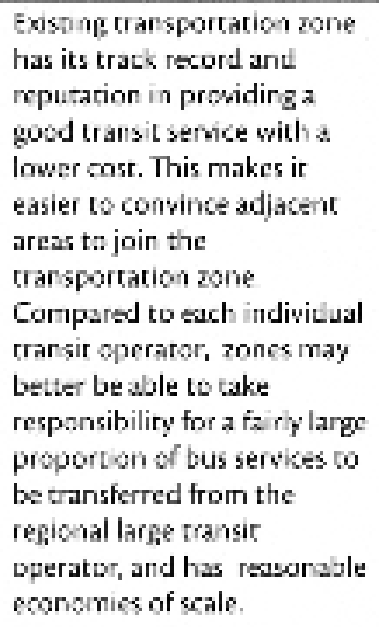 & $\begin{array}{l}\text { Exisnog ransportarion zone } \\
\text { exponsion may be } \\
\text { constrained by rhe } \\
\text { geographic politics, thus } \\
\text { being unable to form the } \\
\text { regionwide subregional } \\
\text { gewernance framewurk. }\end{array}$ \\
\hline Oprion 2 & $\begin{array}{l}\text { Inregranon of seweral } \\
\text { municipal trarsit operators } \\
\text { ro esrablish sworal now } \\
\text { gecgraphically bused } \\
\text { ransporration zones may } \\
\text { help form the regionwide } \\
\text { su/arcgional growernance } \\
\text { framework. }\end{array}$ & $\begin{array}{l}\text { Nost a conscnsus auilding } \\
\text { proces among local } \\
\text { municipal transit aperatars } \\
\text { to form the transportation } \\
\text { zone, whidh is the Joint } \\
\text { Powers Authoricy opA. } \\
\text { There may cost conflicts } \\
\text { between each transt } \\
\text { aperater's interests and } \\
\text { entire zonal interests. Neod } \\
\text { to follow the complicated } \\
\text { transportation zone } \\
\text { applitestion procedures. }\end{array}$ \\
\hline
\end{tabular}




\section{Decentralize Bus Services without Divestiture while Enhancing Local Control}

Both transferring bus routes to municipal transit operators and to transportation zones would carve out existing bus routes from the regional transit operator, which may potentially disrupt existing bus services. Both approaches represent a complete local micro-level control, running the potential risk of sacrificing a regional macro-level control.

To avoid this situation, a compromising alternative emerges. This alternative would reorganize and decentralize existing transportation services under the purview of the regional transit operator into different service sectors. Each service sector is a semi-autonomous unit with more local control and authority delegated from the regional transit operator. Jurisdictionally, each service sector still belongs to the regional transit operator. Under this decentralized governance model, the regional transit operator will be responsible for providing regional transit services and setting agency-wide transit operating policies, whereas service sectors will provide local connector and community transit services at their discretions, and meet local communities' various transit demand. See Figure 4 for the conceptual framework.

\section{Figure 4. Decentralize Bus Service Operation Through Establishing Bus Service Sectors}

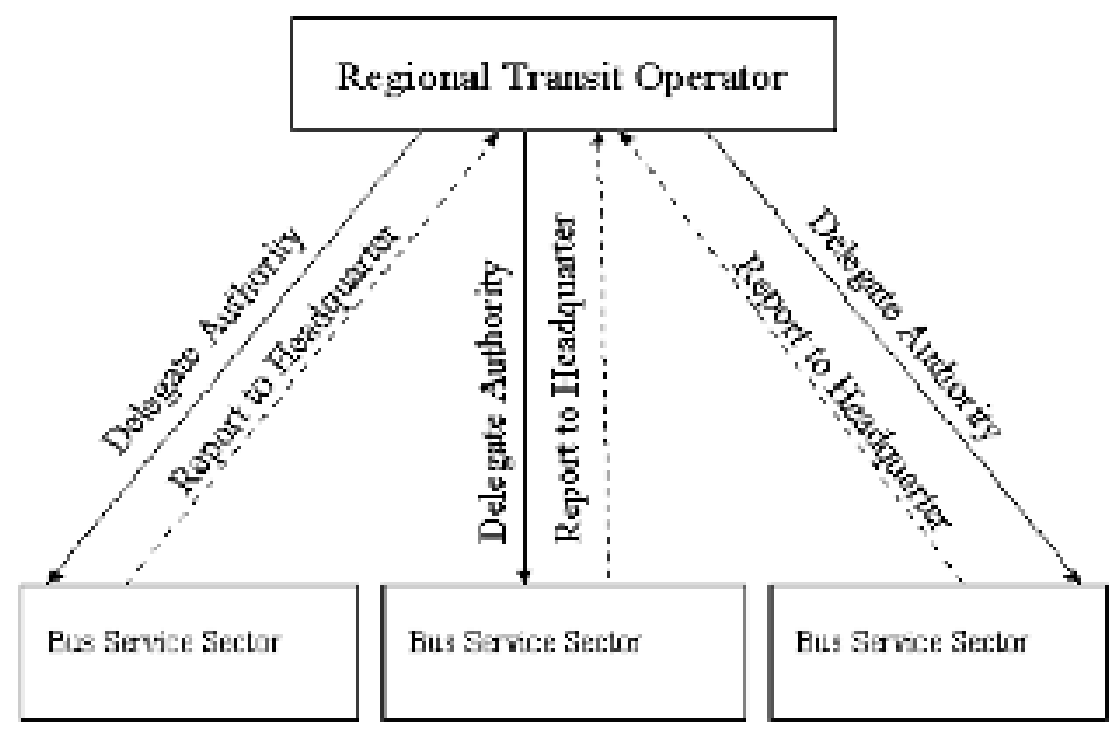


Therefore, this alternative only changes the intra-agency governance model without transferring bus routes out to either municipal operators or transportation zones. The evaluation of this alternative is shown in Table 4.

\section{Table 4. Merits and Demerits of Establishing Service Sectors}

\begin{tabular}{|c|c|c|}
\hline Options & Merits & Demerits \\
\hline Service Sectar & $\begin{array}{l}\text { improve lacal contral } \\
\text { withour losing regional } \\
\text { control. Koep existing } \\
\text { integrarad bus service } \\
\text { delivery systern intatt } \\
\text { withour diwsting bus } \\
\text { services. }\end{array}$ & 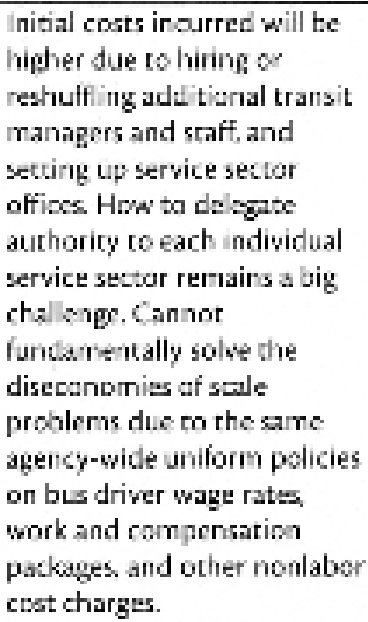 \\
\hline
\end{tabular}




\section{Evaluation}

Tables 2 through 4 suggest that each alternative has its merits and demerits, which are evaluated primarily from the standpoint of bus operation. In fact, each alternative has its distinctive community impacts, cost and revenue implications, legal implications, and operations and service delivery issues. From a pure technical standpoint, it is difficult, if not impossible, to select the best alternative of subregional governance of bus services, because many impacts are hard to be quantified.

In fact, the alternative selection process is highly political. It needs to reflect the political reality and balance competing among different transportation stakeholders. Table 5 lists some potential stakeholders who may have interests in the outcome of any subregional governance alternative selected. Under normal circumstances, a mixed alternative balancing regional interests and local interests will prevail.

Table 5. Primary Stakeholders of Subregional Governance of Bus Services

\begin{tabular}{|c|c|}
\hline Stakeholder Category & Primary Stakeholders \\
\hline Regienal transit operator & $\begin{array}{l}\text { Hargaining unirs } \\
\text { Board of directors } \\
\text { phanagertent and scaff }\end{array}$ \\
\hline Gtunicipal trarsit reperatsers & 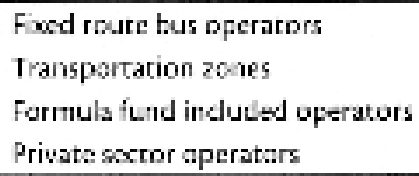 \\
\hline Public & $\begin{array}{l}\text { Bus passengers } \\
\text { Bus riders union } \\
\text { Curnrrunity gruups } \\
\text { Employses }\end{array}$ \\
\hline Covern ment agencies & $\begin{array}{l}\text { Cities } \\
\text { Cauncils of govemnents } \\
\text { County } \\
\text { Joint powers authonties } \\
\text { State guvernment } \\
\text { Federal povernment }\end{array}$ \\
\hline
\end{tabular}




\section{Case Studies of Subregional Governance}

This section introduces the subregional governance of bus services being undertaken in Los Angeles County, with a brief reference to the subregional governance of transit services in the other U.S. cities.

\section{Background}

In early 1998, the Los Angeles County MTA Board of Directors moved that the agency Chief Executive Officer (CEO) return to the board within 90 days with an implementation plan to divest MTA bus services into subregionally governed bus service providers, or zones.

In response to the MTA board motion, a consulting team led by Booz-Allen \& Hamilton Inc. was retained by MTA to perform the technical study. The study report develops and analyzes alternative approaches for divestiture of MTA bus services into subregionally governed operations.

\section{Alternatives of Subregional Governance of Bus Services}

The Booz-Allen \& Hamilton Inc. team proposed the following five alternatives:

1. Expand and leverage the role of existing transit operators.

2. Increase the geographical coverage of the existing Foothill Transit Zone.

3. Add additional local transportation zones where interest and capability to meet guideline requirements exist.

4. Subcontract appropriate individual MTA operating divisions, and provide additional local autonomy.

5. Develop subregional bus service delivery boards within the overall MTA structure to provide greater local control over bus services while maintaining some regional policy control at the MTA Board of Directors level (e.g., fares, aggregate budget).

Each alternative involves different bus service divestiture priorities, stakeholder interests, community impacts, cost and revenue implications, legal implications, and operations and service delivery issues. 


\section{Reasons Why the Original Concept of Transportation Zones Was Abandoned}

Implementing the concept of transportation zones represents complete local control by carving out transportation zones from the MTA bus service area. This "draconian" approach would unnecessarily be destructive to the agency and painful for its employees. Furthermore, if MTA completely gives up control over countywide bus operation, provision of regional transit service and enforcing consent decree may be problematic. The countywide guidance, steering, and coor dination of bus services among different local transit operators may be undermined, as the result of establishing transportation zones. Therefore, the original concept of transportation zones was abandoned.

\section{Culmination of Subregional Governance: New Service Sector Plan}

The MTA is currently in the process of reorganizing its countywide transit operations into five geographically semi-autonomous service sectors (i.e., San Fernando Valley/North County, San Gabriel Valley, Gateway Cities, South Bay, and Central Cities/West) in Los Angeles County. See Figure 5 for the geographic boundaries of the service sectors.

Figure 5. Bus Service Sector Boundaries in Los Angeles County

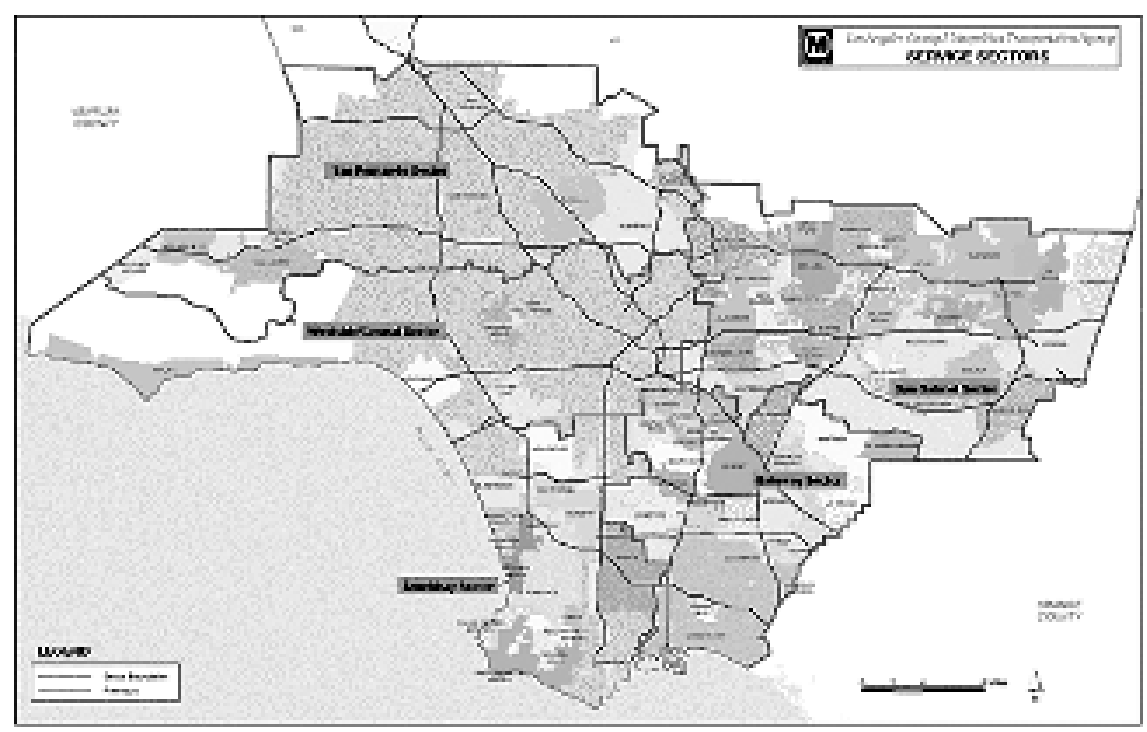


The objectives of the service sector concept are multifold (Metro Investment Report 2002):

- reduce costs while improving the quality of customer service

- respond quickly to community needs

- improve the performance and appearance of buses, and increase ridership with existing resources. As a result, the MTA can be more responsive to customers and to the community when responsibility and accountability are placed at the local level

- reorganize into service sectors to foster improvement in service quality and allow employees to be more creative in shaping and operating service

Highlights of this new service sector concept include:

- The MTA headquarter will have sole responsibility for operating such regional transit services as Metro Rail, Metro Rapid Bus, and express bus service (i.e., Tier 1 transit service).

- The countywide Tier 2 and Tier 3 transit operations (local customer service) and the designated Tier 1 transit operation will be provided by service sectors.

- Service sectors will operate as semi-independent units of the MTA with capabilities similar to a municipal operator. In addition to the staff assigned to bus operations, a service sector would have administrative and community outreach employees, service planners and schedulers, security and other support personnel.

- Utilize existing bus capacity not to exceed 500-600 buses per service sector.

- Collocate management, customer-focused, support functions at service sector operating bases within local communities served.

- Establish new relationships with reinvented MTA corporate support functions.

- Each service sector has its own general manager and council or governing board.

- Managing locally, recruiting locally also meld into the MTA's belief that strong community involvement is essential if service sectors are to be responsive to their customers. 


\section{Table 6. Responsibilities of Headquarter and Subordinate Units}

\begin{tabular}{|c|c|}
\hline Level of Auchority & Responsibilicies \\
\hline MTA Gard bi Dirscoors (Headquarter) & 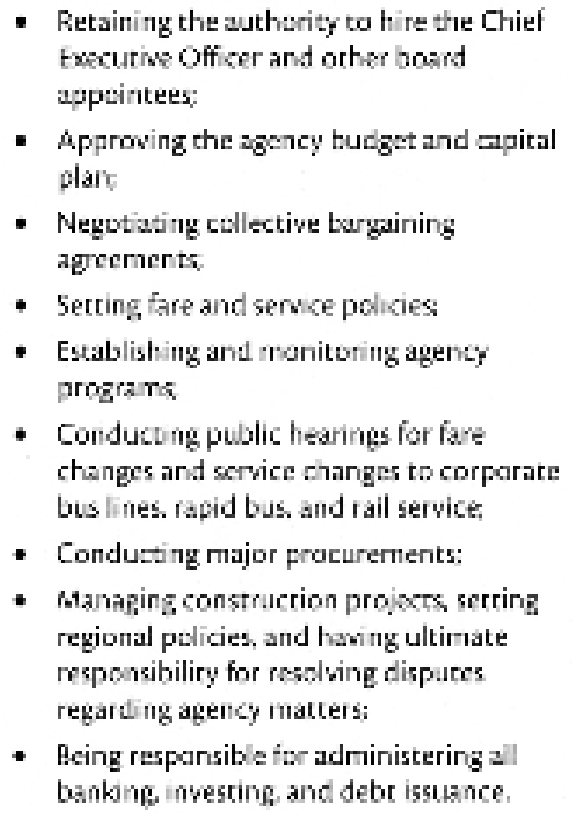 \\
\hline $\begin{array}{l}\text { Sextor Covernance Council } \\
\text { (Suburdinate Unit) }\end{array}$ & 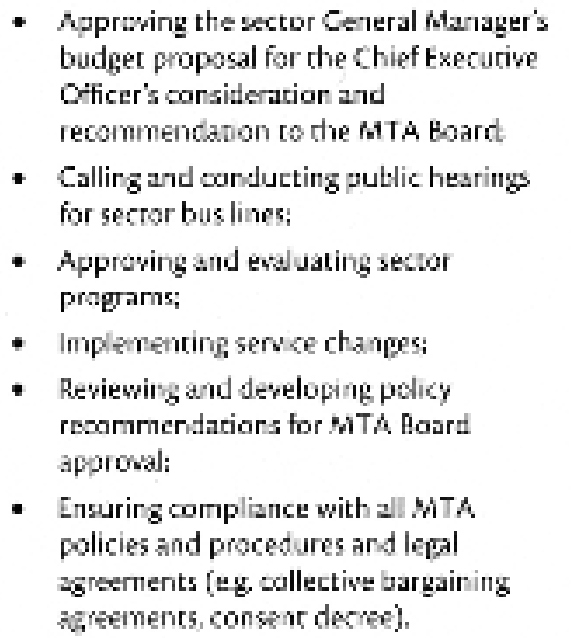 \\
\hline
\end{tabular}


On September 26, 2002, the MTA Board of Directors formally adopted the proposed policy creating the Service Sector Governance Councils. This policy stipulates the distinctive functions assumed by the MTA Board of Directors (Headquarter) and the Service Sector Governance Councils (Subordinate Units), see Table 6 for details. This distinction is very important to better understanding the subregional governance of bus services in Los Angeles County. Due to their recent inception, no performance data of five service sectors is currently available.

The Los Angeles new service sector plan of bus services has followed similar experiments in the other U.S. major cities.

For example, the New York Metropolitan Transportation Authority is comprised of a central "umbrella" agency with a 20-member board that does not operate any services and six "subsidiaries" whose boards are subsets of the members of the central board, including:

- New York City Transit operating buses and rapid transit in the New York Boroughs

- Long Island Railroad operating commuter rail from Eastern suburbs into New York City

- Metro-North Railroad operating commuter rail from Northern suburbs into New York City

- Long Island Bus operating bus services in central Long Island

- Staten Island Railway operating rapid transit rail services on Staten Island

- Bridges and Tunnels operating highway and bridge toll facilities into New York City

The Northwestern Illinois Regional Transportation Authority is also an "umbrella" agency. Its 14-member board oversees finances and budgets for Chicago area services, which are governed by three other independent boards of directors including:

- Chicago Transit Authority operating in the City and County with a 7-member board

- METRA operating commuter rail services for the region also with a 7-member board

- PACE operating bus services in the surrounding suburbs with a 12-member board 
The San Diego Metropolitan Transit Development Board with a 15-member board oversees an amalgam of private and public service providers, two of which (San Diego Transit Corporation and San Diego Trolley Inc.) have separate 7-member boards.

\section{Summary of Findings and Guidelines for Policy Analysis}

In spite of many research efforts already made, subregional governance of bus services still has several unresolved issues worth further researching.

\section{Regional Governance versus Local Governance}

Whether a particular type of bus service should be regionally governed or locally governed is still disputable. Typically, the regionally significant bus routes (e.g., express bus, rapid bus) should be run by the regional transit operator. Eligible regionally significant bus routes may need to meet several criteria, such as (Los Angeles County MTA 1999):

- the line must travel between two or more subregions

- have a high percentage of passengers making longer trips

- have a high percentage of interaction with other bus routes

- have a relatively higher ridership

- have the propensity to offer relatively faster bus speeds

- have the potential for limited stop service

If the regionally significant bus routes have very poor benefit/cost ratios, should they simply be divested, restructured, or entirely eliminated? Intercommunity and local bus routes may be good candidates for subregional governance due to the nature of their local service coverage. Care must be taken to ensure that the connectivity to other regions not be impaired. Otherwise, people who travel between subregions may find their mobility worsened, and their travel times may be lengthened due to lack of adequate schedule connections with other bus service. To further strengthen regional connectivity after implementing subregional governance, uniform fare system should be implemented to integrate different transit operators and allow travelers to have smooth transfers among different bus routes.

\section{Most Efficient Bus Fleet Size for a Transportation Zone}

According to the 1999 Local Transportation Zone Guidelines of the Los Angeles County MTA, a transportation zone is defined as a geographically contiguous area 
with at least one major trip generator and more than half of all routes to be transferred to the zone have an average transit trip length of less than five miles.

The boundary of a transportation zone is determined based on such factors as travel patterns, geographic barriers, demographic characteristics, historical/cultural factors, and political considerations.

However, given a particular set of local conditions, it is unclear what bus fleet size is most efficient for a transportation zone in terms of yielding the highest economies of scale. In developing the Los Angeles bus service sector concept, a 400- to 500bus fleet size was assumed to be most efficient. This figure may better reflect the existing bus fleet size within each subregion of the County rather than the "optimal” bus fleet size.

\section{Delegation of Authority from Regional Transit Operator to each Service Sector}

It is critical to determine how much and what types of authorities should reside with the regional transit operator or reside with each service sector. How to coordinate the decentralized transit scheduling and operation process with the still centralized countywide transportation planning process remains a key issue.

Under the bus service sector concept, uniform fare policies are still set by the regional transit operator. Fare structures typically include base cash fare, transfer fare, aged and disabled fare, tokens, and passes. Due to different demographic and socioeconomic conditions among different subregions, uniform fare policies have problems. To promote geographic equity, fare policy setting is suggested to be localized as well. Poor areas should get lower fares, whereas rich areas should be charged a little more to be more equitable.

\section{Geographically-based Subregional Governance versus Locally-Concentrated Transit Problems}

Since most transit-dependent people live in the inner cities of metropolitan areas, will the countywide transit operation decentralization measure actually improve customer service for inner-city transit-dependent people? The answer is probably no. Instead of evenly decentralizing resources in terms of providing similar bus fleet size among five service sectors, it may be more worthwhile to shift more resources to inner-city service sectors to provide more direct transit services. Suburban travel is auto-dominated with limited transit ridership. In other words, different subregions should receive different priorities in devising subregional governance frameworks due to the uneven distribution of transit-dependent people. 


\section{Conclusions}

Subregional governance of bus services is a popular planning strategy being implemented in the United States, especially in large and politically complicated metropolitan areas with diverse interests.

On the one hand, properly structured subregional governance of bus services may yield better economies of scale, enhance local control, and improve bus operations to better meet customers' ever-changing demands. But on the other hand, subregional governance of bus services may run the potential risk of causing lack of coordination among subregional transit operators in terms of having consistent bus operating schedules and fare media acceptance policies.

To improve this situation, regional bus services normally reside with the regional transit operator, and the inefficient inter-community or local bus services are transferred to the smaller transit units, in the form of divestiture or decentralization. Though bigger government is not a better government, a small-scale government is not automatically a better government, either. Therefore, the boundary line between regional bus services and local bus services should properly be drawn to determine the appropriate governance model. The uniform fare system should be established to smooth inter-route transfers and inter-agency coordination.

The subregional governance of bus services still has many unresolved research questions (e.g., the threshold between regional governance and subregional governance, most efficient bus fleet size for a transportation zone, distinction between regional governing board authority and subregional governing board authority, and consistency of subregional governance alternatives with the overall suburbanization trend in the United States). These questions still call for further research efforts which may or may not achieve consistent results. 


\section{References}

Booz-Allen \& Hamilton Inc. in association with KPMG Peat Marwick LLP and Riordan \& McKinzie. 1998. Report to the Metropolitan Transportation Authority on subregional governance of MTA bus services. Los Angeles, CA: Los Angeles County Metropolitan Transportation Authority (MTA).

Deb, Kaushik. 2002. Restructuring urban public transport in India. Journal of Public Transportation 5 (3).

Keohane, R., and Joseph S. Nye. 2000. Introduction. In Nye, Joseph S., and John D. Donahue (eds.). Governance in a Globalizing World. Cambridge, MA: Visions of Governance for the 21st Century.

Los Angeles County Metropolitan Transportation Authority (MTA). 1999. Local transportation zone guidelines. Los Angeles, CA: Los Angeles County Metropolitan Transportation Authority.

Lowery, David. 2002. Book Review on Laurence E. Lynn, Jr., Carolyn J. Heinrich, and Carolyn J. Hill. 2001. Improving governance: A new logic for empirical research. Journal of Public Administration Research and Theory 12 (2): 293.

Lynn, Laurence E., Jr., Carolyn J. Heinrich, and Carolyn J. Hill. 2000. Studying governance and public management: Challenges and prospects. Journal of Public Administration Research and Theory 10 (2): 233.

Metro Investment Report. 2002. MTA's new sector plan prioritizes service, empowers workers \& infuses creativity IX (10).

Peters, B. Guy, and Donald J. Savoie. 1995. Governance in a changing environment. Montreal \& Kingston, Canada: Canadian Centre for Management Development.

Schipper, L. 2002. Sustaining urban transport in the $21^{\text {st }}$ century: Challenges for the developing world. Washington, DC: Transportation Research Board Annual Meeting Proceeding CD-ROM.

Weslin Consulting Services. 2000. Subregional government alternatives study. Los Angeles, CA: Los Angeles County Metropolitan Transportation Authority (MTA).

Williamson, Oliver E. 1999. Public and private bureaucracies: A transaction cost economics perspective. The Journal of Law, Economics, and Organization 15 (1): 306-342. 


\section{About the Author}

Xueming Chen (xueming.chen@csun.edu) is an adjunct professor in the Department of Urban Studies and Planning at California State University, Northridge (CSUN), and a senior transportation planning manager with the Los Angeles County Metropolitan Transportation Authority (MTA). Dr. Chen is a registered full member of the American Institute of Certified Planners (AICP) and the Institute of Transportation Engineers (ITE). He currently serves on the Transportation Research Board (TRB) Committee A1C01 (Transportation Economics) and Committee A1A06 (Transportation and Economic Development). Dr. Chen received his Ph.D. degree in urban and regional planning from the University of Southern California. 